

\section{DISCLAIMER}

This report was prepared as an account of work sponsored by an agency of the United States Government. Neither the United States Government nor any agency Thereof, nor any of their employees, makes any warranty, express or implied, or assumes any legal liability or responsibility for the accuracy, completeness, or usefulness of any information, apparatus, product, or process disclosed, or represents that its use would not infringe privately owned rights. Reference herein to any specific commercial product, process, or service by trade name, trademark, manufacturer, or otherwise does not necessarily constitute or imply its endorsement, recommendation, or favoring by the United States Government or any agency thereof. The views and opinions of authors expressed herein do not necessarily state or reflect those of the United States Government or any agency thereof. 


\section{DISCLAIMER}

Portions of this document may be illegible in electronic image products. Images are produced from the best available original document. 


\section{Printed in the United States of America. Available from National Technical Information Service \\ U.S. Department of Commerce \\ 5285 Port Royal Road, Springfield, Virginia 22161 \\ NTIS price codes-Printed Copy: AO3. Microfiche A01 02}

This report was prepared as an account of work sponsored by an agency of the United States Government. Neither the United States Government nor any agency thereof, nor any of their employees, makes any warranty, express or implied, or assumes any legal liability or responsibility for the accuracy, completeness, or usefulness of any information, apparatus, product, or process disclosed, or represents that its use would not infringe privately owned rights. Reference herein to any specific commercial product, process, or service by trade name, trademark, manufacturer, or otherwise, does not necessarily constitute or imply its endorsement, recommendation, or favoring by the United States Government or any agency thereof. The views and opinions of authors expressed herein do not necessarily state or reflect those of the United States Government or any agency thereof. 
ORNL/Sub-7715/1

Dist. Category UC-95d

Contract No. W-7405-eng-26

\title{
OPERATING TEMPERATURES FOR A CONVECTIVELY COOLED RECESSED INCANDESCENT LIGHT FIXTURE
}

\author{
D. W. Yarbrough and I. Toor \\ Department of Chemical Engineering \\ Tennessee Technological University \\ Cookeville, TN 38501 \\ Subcontract No. 7715 \\ Date Published: December 1980

\section{Part of} \\ The National Program for \\ Building Thermal Envelope Systems and \\ Insulating Materials
}

Research sponsored by the Office of Buildings and Communily Syslems, Buildings Divisiun

U.S. Department of Energy

OAK RIDGE NATIONAL LABORATORY

Oak Ridge, Tennessee 37830 operated by

UNION CARBIDE CORPORATION

for the DEPARTMENT OF ENERGY

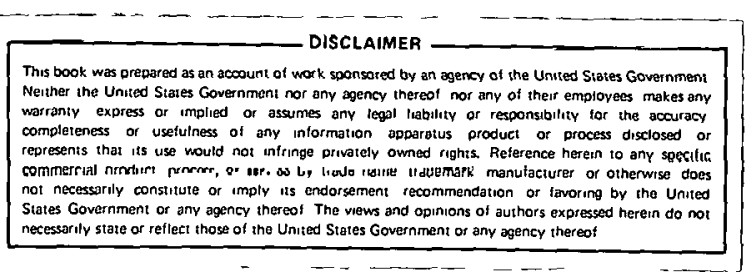


THIS PAGE

\section{WAS INTENTIONALLY LEFT BLANK}


FOREWORD

This is one of a series of reports to be published describing research, development, and demonstration activities in support of the National Program for Building Thermal Envelope Systems and Insulating Materials. The National Program involves several federal agencies and many other organizations in the public and private sectors who are addressing the national objective of decreasing energy wastes in the heating and cooling of buildings. Results described in this report are part of the National Program through delegation of management responsibilities for the DOE lead role to the Oak Ridge National Laboratory.

Ted S. Lundy

Program Manager

Building Thermal Envelope Systems and Insulating Materials

Oak Ridge National Laboratory

[. C. Freeman

Program Manager, Buildings Division

Office of Buildings and Community Systems

Department of Energy 


\section{THIS PAGE}

\section{WAS INTENTIONALLY LEFT BLANK}


1. DOE/CS-0059: The National Program Plan for Building Thermal Envelope Systems and Insulating Materials (January 1979).

2. LBL-8822: A New Measurement Strategy for In-Situ Testing of Wall Thermal Performance (March 1979).

3. LBL-8925: Thermal Performance of Buildings and Building Envelope Systems: An Annotated Bibliography (March 1979).

4. ORNL/SUB-7556/I : Assessment of the Corrosiveness of Cellulosic Insulating MateriaTs (June 1979).

5. ORNL/SUB-7504/3: Recessed Light Fixture Test Facility (July 1979).

6. ORNL/SUB-7559/I: Problems Associated with the Use of UreaFormaldehyde Foam for Residential Insulation (September 1979).

7. ORNL/Sub-7551/I: Interim Progress Report on an Investigation of Energy Transpor $t$ in Porous Insulator Systems (october 1979).

8. ORNL/TM-6494: A Technique for Measuring the Apparent Conductivity of Flat Insulations (October 1979).

9. LBL-9821: Measurement of In-Situ Dynamic Thermal Performance of Building Envelopes Using Heat Flow Meter Arrays (December 1979).

10. ORNL/Sub-79/13660/I : Minnesota Retrofit Insulation In Situ Test Program Extension and Review (February 1980).

11. ORNL/TM-7266: An Experimental Study of Thermal Resistance Values (R-Values) of Low-Density Mineral-Fiber Building Insulation Batts Commercially Available in 1977 (Aprit 1980).

12. NBS/BS Series 123: The Effect of Molsture on the Thermal Conductance of Roofing Systems (ApriT 1980).

13. ORNL/Sub-78/97726/I : A Field Study of Moisture Damage in Walls Insulated Without a Vapor Barrier (May 1980).

14. ORNL/CON-46: An Appraisal of the M Factor and the Role of Building Thermal Mass in Energy Conservation (JuTy 1980).

15. ORNL/Sub-7686/I : Smoldering Combustion Hazards of Thermal Insulation Materials (July 1980).

16. NBSIR 80-2097: Precision Measurements on Fibrous Glass Insulation (JuTy 1980). 
17. NBSIR 80-2085: Fire Performance of Loose-Fill Cellulosic Insulation in Residential Occupancies (August 1980).

18. ORNL/Sub-7556/II: Corrosion Testing of Urea-Formaldehyde Foam Insulating Materials (September 1980). 
Test results are given in this report for the operation of a recessed incandescent light fixture intended for residential use. The fixture which has been designed and marketed by Thomas Industries, Inc. is labeled for use in direct contact with attic thermal insulation. Temperature control of the powered fixture is provided by convective heat transfer from the ceiling side of the fixture.

The fixture was operated at power levels up to two times the rated power of 75 watts and under thermal insulations up to $\mathrm{R}-40$. In all operating configurations tested the fixture surface in contact with attic insulation was found to be less than $175^{\circ} \mathrm{C}$. The observed surface temperatures are judged to be safe for operation in contact with loose-fill or batt-type insulations.

It was observed that the power leads inside one fixture configuration are exposed to temperatures as high as $163^{\circ} \mathrm{C}$. The electrical insulation could, therefore, have a limited life. The properties of the internal fixture wiring were not, however, studied in detail. 
THIS PAGE

\section{WAS INTENTIONALLY LEFT BLANK}


Operating Temperatures for a Convectively Cooled

Recessed Incandescent Light Fixture

\section{Introduction}

A previous study ${ }^{(1)}$ of recessed light fixtures showed that operation of fixtures covered by thermal insulation resulted in temperatures in excess of $200^{\circ} \mathrm{C}$. Combinations of insulation-covered recessed fixtures and combustible insulation were, consequently, identified as a potential fire hazard. The suggestion was also made that the operating temperatures of the tested fixtures could be lowered by promoting heat transfer away from the fixture by convection-conduction to the air on the ceiling side.

A recessed fixture has been marketed with a label declaring that it can be operated in direct contact with attic thermal insulation. The fixture is open to the air on the ceiling side to provide cooling. A sample of the new fixture was obtained through normal distribution channels, instrumented, and operated at three power levels to determine maximum steady state operating temperatures under attic thermal insulation.

\section{Expcrimcntal apparatus and procedure}

The experimental procedure used in this work was similar to that described in a previous report on the test facility. (1) The fixture to be tested was mounted in a $24 \times 48$-inch box that is 9 inches deep with $\frac{1}{2}$-inch sheet rock used to simulate a ceiling. Copper-constantan thermocouples were mechanically

(1) "Recessed Light Fixture Test Facility", D. W. Yarbrough, K. T. Yoo, and P. B. Koneru, ORNL/SUB-7504/3, Oak Ridge National Laboratory, Oak Ridge, Tennessee 37830 
fixed to the attic side surface of the fixture. This was done by drilling small holes in the body of the fixture and attaching the thermocouples to the fixture with sheet metal screws. One thermocouple was attached to the ceiling side trim in a similar manner. The thermal EMF's produced by the several thermocouples were measured relative to an ice bath using a digital multimeter ${ }^{(2)}$ and converted to temperatures using thermocouple reference tables. (3) 'lemperature determination is judged to be accurate to within $\pm 1^{\circ} \mathrm{C}$. (4) Figure 1 shows the positioning of the fixture within the test section and the location of the thermocouples on the fixture. Figures 2 through 4 are photographs of the instrumented fixture and trims that were studied.

The fixture was thermally insulated on the attic side with ten inches of loose-fill rock wool insulation installed at a density of approximately $2.6 \mathrm{lbs} / \mathrm{ft}^{3}$. The depth of loose-fill insulation directly above the fixture was 3.5 inches. In addition to the loose-fill insulation, R-13 fiberglass batts were placed on top of the loose $f i l l$ in order to determine operating temperature increase due to increased attic side thermal insulation. Fixture operating temperatures were recorded for attic side insulations approaching $\mathrm{R}-40$.

(2) Hewlett Packard 3405A Digital Voltmeter with stated accuracy $\pm(2 \mu \mathrm{V}$ $+0.03 \%$ of reading).

(3) "Thermocouple Reference Tableo Baocd on the IPTS-68", Robert L. Powell et al., N.B.S. Monograph 125.

(4) Thermocouples were checked against the ice point and steam point. The error at the ice point was estimated to be less than $0.1^{\circ} \mathrm{C}$. The error at the steam point was estimated to be less than $0.3^{\circ} \mathrm{C}$. 


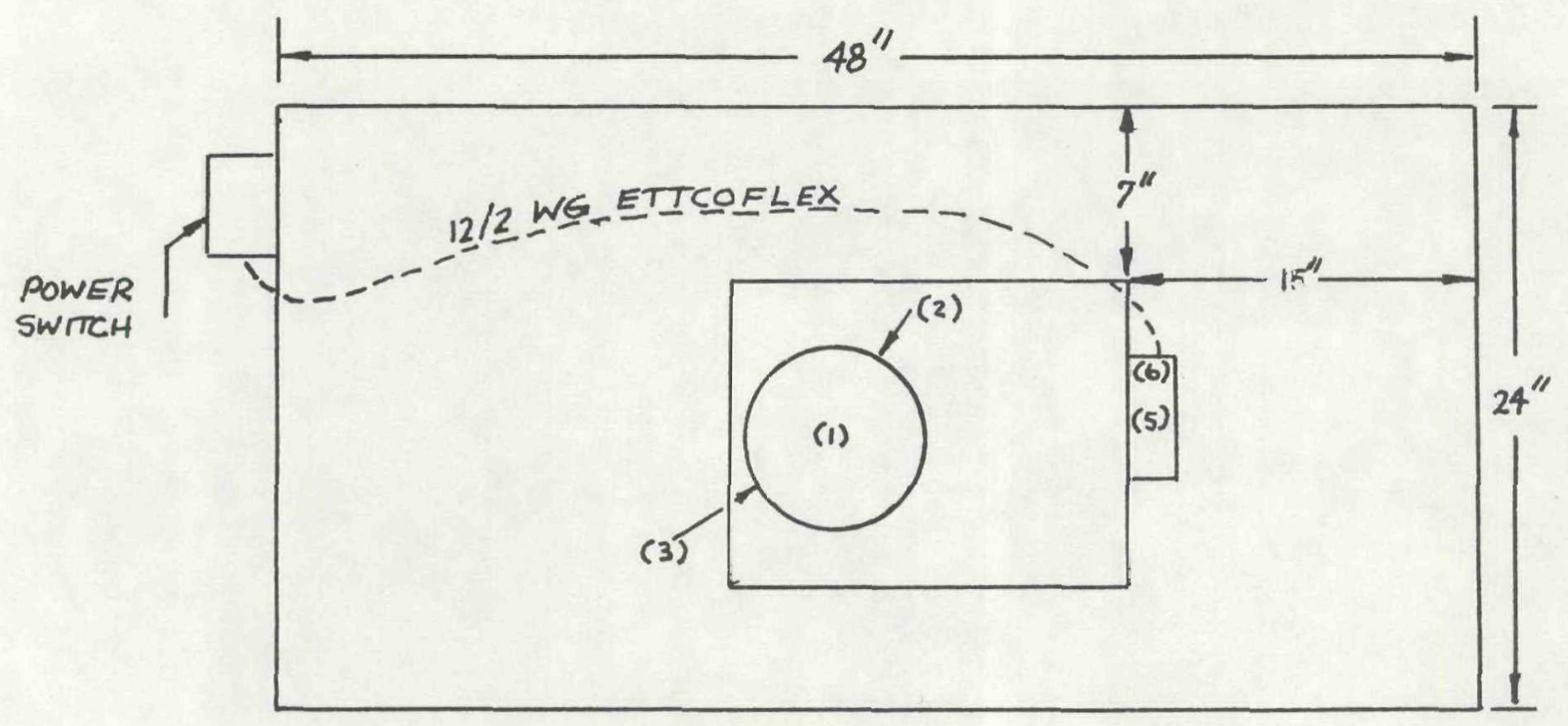

Thermocouple Locations

(1) Top of Fixture

(2), (3) Side of Fixture, $2 \frac{1}{2}$ inches above Base Plate

(4) Ceiling Side Trim (see Figs.3 and 4)

(5), (6) Electrical Connector Box

Figure 1. Top View of Recessed Fixture Test Section 


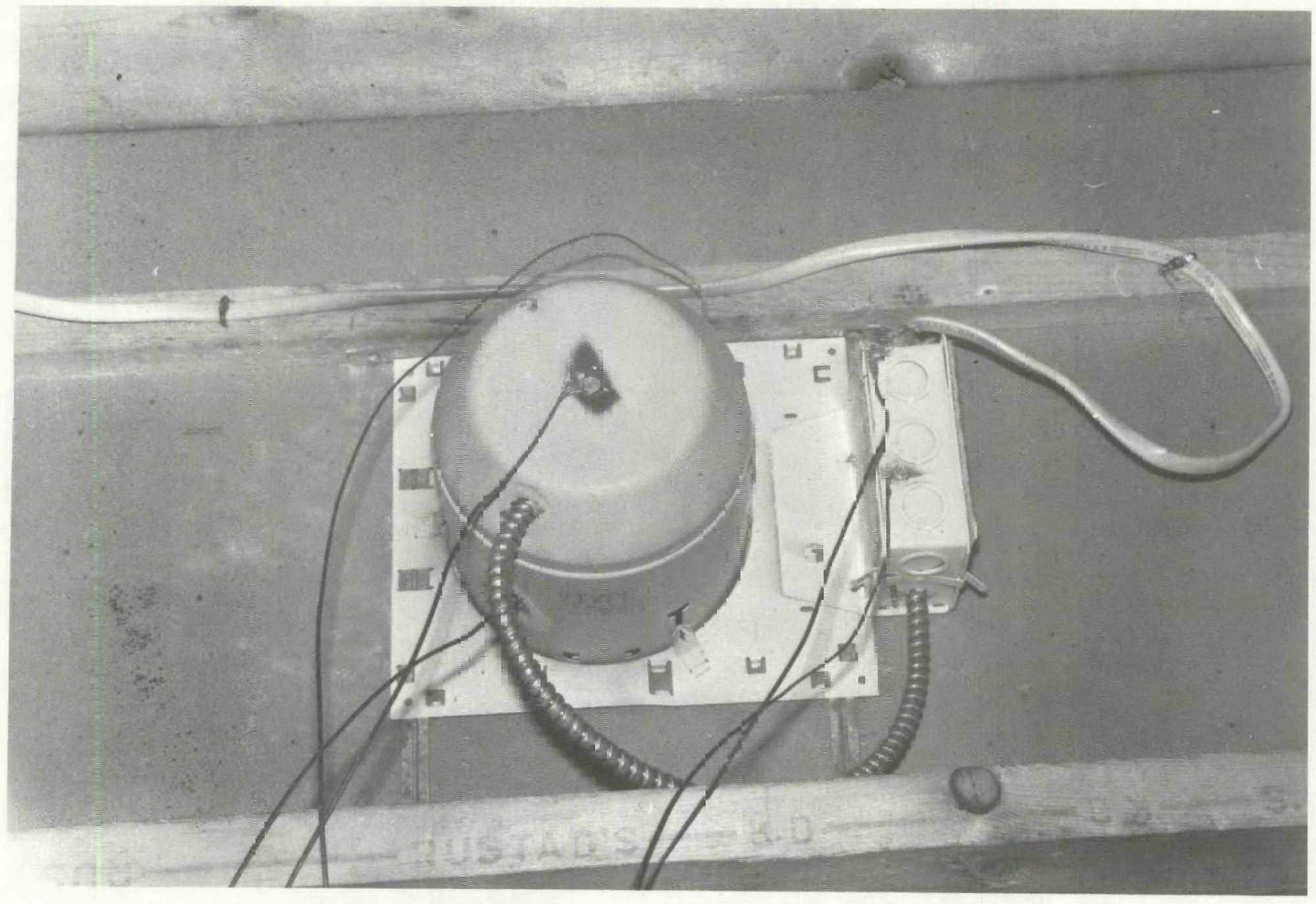

Figure 2. Protograph of the Irstrumented Fixture. 


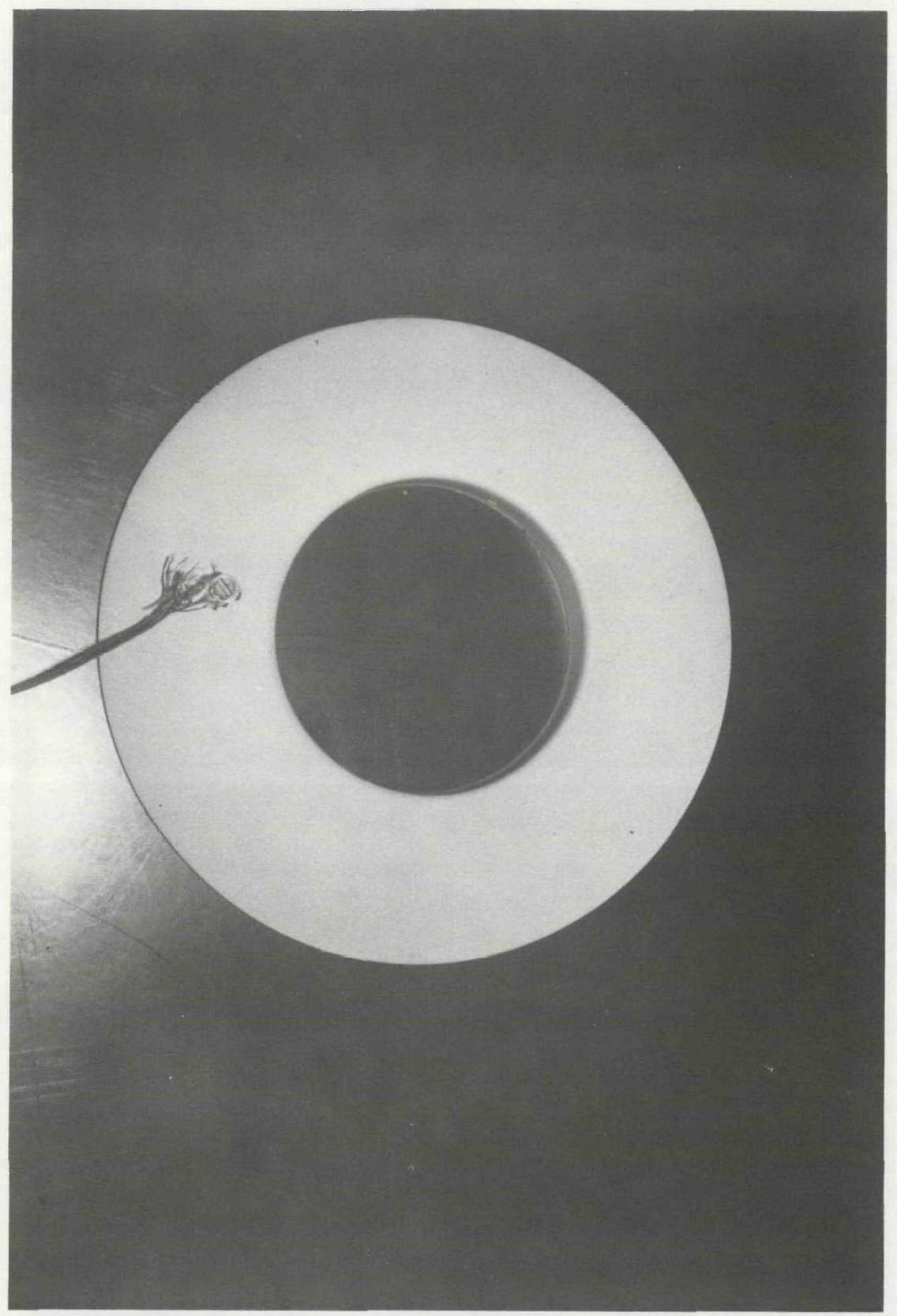

Figure 3. Fixture Trim R-232-W with Thermocouple Attached. 


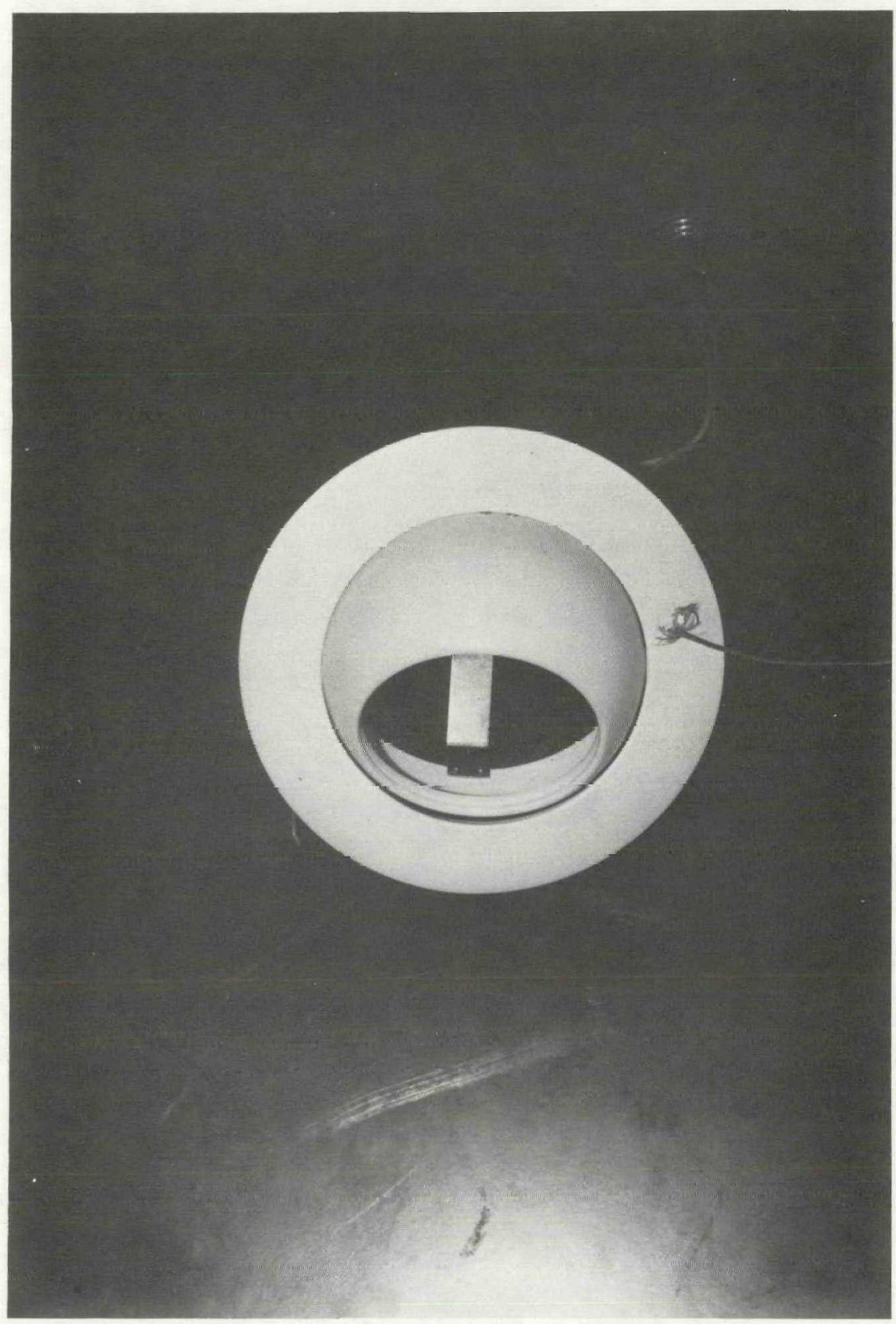

Figure 4. Fixture Trim R-230-W with Thermocouple Attached. 
The fixture that was tested is identified by the manufacturer, Thomas Industries, Inc. (5), as model number $\mathrm{R} 1-1 \mathrm{C}$. It is rated at 75 watts by the producer and can be installed with any one of six ceiling side trims. The present series of tests were completed with two typical trims. The first was model number R-232-W (Figure 3) which is a flat ring of metal that is installed flush with the ceiling. Trim R-232-W has a ceiling side open space approximately four inches in diameter. The second trim used, R-230-W (Figure 4), has the appearance of a spotlight which directs light away from the vertical. It also has an open space approximately four inches in diameter.

The fixture was operated with $75,100,150$, and 200 watt bulbs installed. The 200 watt bulbs were found to protrude from the fixture and were judged, therefore, to represent an unrealistic configuration. Both the ceiling side and the attic side of the test section were in contact with room air at $20-24^{\circ} \mathrm{C}$. In each case the fixture was operated for a continuous period long enough lo establish steady state.

Ceiling side trim temperatures were measured by a mechanically attached thermocouple. The trim temperature is of interest since it affects surrounding painted surfaces.

\section{Discussion of results}

Table 1 shows the steady state temperatures that were observed for the attic side fixture surface and the ceiling side trim. Duplicate entries for a given configuration show the changes resulting from removal and replacement of the thermal insulation. Power variations and ambient temperature variations also affect the steady state operating temperatures. The maximum observed temperatures were on the box containing the electrical connec-

(5) Thomas Industries, Inc., Residential Lighting Division 207 East Broad, Louisville, KY 40232 
tion of the fixture to the power supply. Thermocouples were exchanged and circuit resistances were checked to verify the observed temperatures. The connector box is attached to the fixture body by a metal plate. The connecting plate is covered by the maximum insulation depth. The present results indicate that the maximum observed temperatures on the fixture surface result from heat conduction along the base plate.

The results in Table 1 show steady state temperatures in the range $90^{\circ} \mathrm{C}$ to $123^{\circ} \mathrm{C}$ for operation at 75 watts under thermal insulation. The maximum surface tempcrature observed was $171^{\circ} \mathrm{C}$ which resulted from operation of the insulated fixture with trim $R-232-W$ and a 150 watt bulb. The observed surface temperatures are judged to be safe for operation with loose-fill fiberglass, rock wool or cellulose insulation or insulating batts.

The electrical connection of the lamp socket to the porser supply using trim $\mathrm{R}-230-\mathrm{W}$ is such that the wiring is exposed to direct heating from the incandescent lamp. A thermocouple was attached to one of the wires to determine the exposure temperature of the electrical insulation. Temperatures as high as $127^{\circ} \mathrm{C}$ were observed when the insulated fixture was operated at 75 watts and $164^{\circ} \mathrm{C}$ when the fixture was operated at 100 watts. It was alsn noted that the electrical wiring in the connector box is eaposed to relatively high temperatures when the fixture is thermally insulated. Examination of the wiring in the connector box revealed discoloration of the electrical insulation helieved due to operation at high temperature. The box carries a statement that $60^{\circ} \mathrm{C}$ rated wire should be used. The insulated fixture, however, operates well above $60^{\circ} \mathrm{C}$. The temperature environment of the electrical insulation could result In rapid deterioration of the insulation which will affect the useful life of the fixture. A detailed analysis of the characteristics of the electrical insulation was not undertaken but should be considered by the manufacturer. 
Table 1

Steady State Operating Temperatures for the

Thomas R1-1C Recessed Light Fixture

Thermal Insulation Bulb size Observed temperatures $\left({ }^{\circ} \mathrm{C}\right)$ (Estimated R-value) (watts) Location (a)
(1)
(2)
(4)
(5)

Maximum Observed Temperature $\left({ }^{\mathrm{O}} \mathrm{C}\right)$

Trim Number $\mathrm{R}-232-\mathrm{W}(\mathrm{b})$

$\begin{array}{lrllllll}27 & 75 & 107 & 107 & 107 & & 118 & 118 \\ 27 & 75 & 110 & 110 & 110 & & 120 & 120 \\ 27 & 75 & 107 & 107 & 106 & 107 & 118 & 118 \\ 40 & 75 & 111 & 111 & 111 & 112 & 123 & 123 \\ 40 & 100 & 134 & 134 & 134 & 133 & 146 & 146 \\ 27 & 150 & 156 & 156 & 156 & & 167 & 167 \\ 40 & 150 & 161 & 161 & 161 & 158 & 171 & 171 \\ 40 & 200 & 150 & 150 & 150 & 148 & 161 & 161\end{array}$

Trim Number R-230-W

$\begin{array}{rrrrrrrrr}0 & 75 & 39 & 38 & 37 & 37 & 44 & 44 & 44 \\ 40 & 75 & 96 & 97 & 96 & 103 & 107 & & 107 \\ 40 & 75 & 81 & & 81 & 88 & 91 & 91 & 91 \\ 40 & 75 & 81 & & 81 & 87 & 90 & 90 & 90 \\ 40 & 75 & 86 & 87 & 86 & 92 & 96 & 96 & 96 \\ 40 & 75 & 94 & 95 & 94 & 97 & 114 & 114 & 114 \\ 40 & 100 & 118 & 119 & 118 & 125 & 129 & & 129 \\ 40 & 100 & 104 & & 103 & 111 & 113 & 114 & 114 \\ 40 & 100 & 99 & & 99 & 107 & 110 & 110 & 110 \\ 40 & 150 & 136 & 136 & 136 & 143 & 147 & & 147 \\ 40 & 150 & 122 & 123 & 122 & 128 & 133 & 133 & 133 \\ 40 & 150 & 120 & 120 & 120 & 126 & 131 & 131 & 131 \\ 40 & 150 & 126 & 126 & 125 & 131 & 137 & 137 & 137 \\ 40 & 150 & 132 & 133 & 132 & 134 & 142 & 142 & 142\end{array}$
a) Thermocouple Locations are shown in Figure 1
b) Thomas Industries, Inc. Part Number 


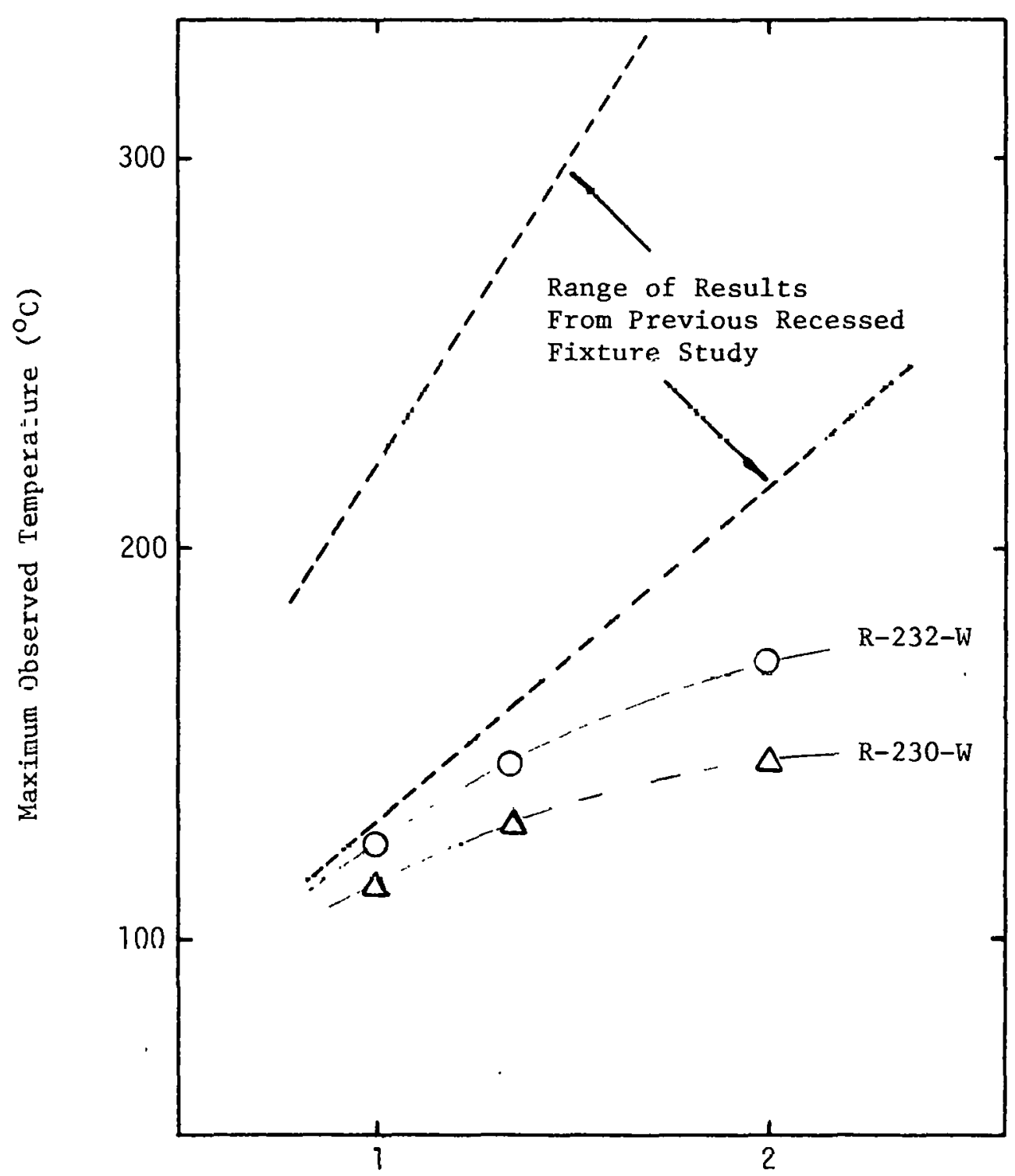

Power to Fixture/75.0

Figure 5. Maximum Observed Temperatures for Tliumas R1-1C Recessed Light f'ixture 
A graphical presentation of the temperature data is given in Figure 5 . The range of operating temperatures for previously tested thermally insulated recessed fixtures ${ }^{(1)}$ is shown in the figure for comparison.

\section{Conclusions}

- The Thomas Industries, Inc. R1-1C recessed fixture operated at temperatures below $175^{\circ} \mathrm{C}$ for all configurations tested. The fixture was operated at 150 watts and under thermal insulations up to $\mathrm{R}-40$.

The fixture when operated at rated power is safe from hazards associated with the surface temperature of the fixture.

The internal wiring associated with trims of the type represented by R-232-W should be redesigned to prevent deterioration of the electrical insulation with time.

- Rapid deterioration of the electrical insulation on the wiring in the connector box might result from operation of the fixture under thermal insulation. 
THIS PAGE

\section{WAS INTENTIONALLY \\ LEFT BLANK}


ORNL/Sub-7715/1

Dist. Category UC-95d

INTERNAL DISTRIBUTION

1-2. Central Research Library

3. Document Reference Section

4-5. Laboratory Records

6. Laboratory Records, ORNL RC

7. ORNL Patent Office

8-32. M\&C Division Office

33. R. S. Carlsmith

34. P. T. Carlson

35. K. W. Childs

36. F. A. Creswick

37. R. G. Donnelly

38. C. S. Dudney

39. W. Fulkerson

40. M. Guthrie

41. W. W. Harris

42. D. R. Johnson
43. T. S. Lundy

44. M. C. Matthews

45. D. L. McElroy

46. J. W. Michel

47. R. E. Minturn

48. E. G. Preston

49. J. N. Robinson

50. M. W. Rosenthal

51. T. F. Scanlan

52. A. C. Schaffhauser

53. J. 0. Stiegler

54. D. B. Trauger

55. J. R. Weir, Jr.

56. R. L. Wendt

57-66. D. W. Yarbrough

\section{EXTERNAL DISTRIBUTION}

67. P. R. Achenbach, 1322 Kurtz Road, McLean, VA

68. J. Adams, Lawrence Berkeley Laboratory, Berkeley, CA

69. R. W. Anderson, 7090 Tecumseh Lane, Chanhassen, MN

70. V. 0. Bahel, Portland Cement Association, Skokie, IL

71. E. L. Bales, DOE/BCS, Washington, DC

72. J. Barnhart, TIMA, Mt. Kisko, NY

73. R. W. Beausoliel, National Bureau of Standards, Gaithersburg, MD

74. A. L. Berlad, State University of New York, Stony Brook, NY

75. J. J. Boul in, DOE/BCS, Washington, DC

76. W. Brenner, National Institute of Building Sciences, Washington, DC

77. J. Cable, DOE/BCS, Washington, OC

78. S. H. Cady, MIMA, Summit, NJ

79. W. Carroll, Lawrence Berkeley Laboratory, Berkeley, $\mathrm{CA}$

80. T. Castino, Underwriters Laboratory, North Brook, IL

81. A. Castle, CPSC, Washington, DC

82. H. I. Cohen, CPSC, Washington, DC

83. R. W. Cole, New Mexico Energy Institute, Albuquerque, NM

84. G. E. Courville, Fairleigh Dickinson University, Teaneck, NJ

85. S. Davis, National Bureau of Standards, Gaithersburg, MD

86. M. W. Dizenfeld, HUD, Washington, DC

87. R. S. Dougal1, University of Pittsburgh, Pittsburgh, PA

88. W. Edmounds, Owens Corning Fiberglas, Washington, DC 
89. W. P. Ellis, H. B. Fuller, Co., Spring House, PA

90. A. E. Fiorato, Portland Cement Association, Skokie, IL

91. C. W. Frank, University of Iowa, Oakdale, IA

92-101. E. C. Freeman, DOE/BCS, Washington, DC

102. L. S. Galowin, National Bureau of Standards, Washington, DC

103. B. F. Gilmartin, Owens-Corning Fiberglas, Washington, DC

104. S. B. Glickman, Lightolier, Inc., Jersey City, NJ

105. L. R. Glicksman, MIT, Cambridge, MA

106. D. Goldenburg, TRW, Inc., Oak Ridge, TN

107. F. A. Govan, Combustion Equipment Assoc., Stamford, CT

108. A. Greenburg, Geo-Energy Ltd., Port Jervis, NY

109. R. F. Hemphi11, TVA, Chattanooga, TN

110. C. Hol lowe 11, Lawrence Berkeley Laboratory, Berkeley, CA

111. J. G. Hust, National Bureau of Standards, Boulder, CO

112. R. R. Jories, Naliund 1 Bureau of Standards. Gaithersburg. MD

113. W. Kleinfelder, Underwriters Laboratories, Inc., Northbrnok, Il.

114. W. M. Kroner, Rensselaer Polytechnic Institute, Troy, NY

115. R. A. Lacrosse, CIMA. Elk Grove Village, IL

116. L. E. LaFehr, International Assoc. of Electrical Inspectors, Park Ridge, IL

117. D. Lamb, TVA, Chattanooga, TN

118. N. W. Lane, Lane Instruments, El Cajon, CA

119. S. Launey, DOE/BCS, Washington, DC

120. E. Lisee, ACEC Research \& Management Foundation, Washington, DC

121. K. R. Long, University of Iowa, Iowa City, IA

122. J. C. McGee, Tennessee Technological University, Cookeville, TN

123. J. T. Miller, GSA, Washington, DC

124. W. V. Miller, Civil Engineering Laboratory, Port Hueneme, CA

125. J. F. Millhuine, DOE/BCŚ, Washiriglun, DC

126. D. E. Muryerrulh, Owens-Corning Fibèrgias, Toledo, UH

127. L. Mulliqan, CPSC, Washington, DC 20207

128. W. R. Newton, TVA, Chattanooga. TN

129. T. J. Ohlemiller, National Bureau of Standards, Gaithersburg, MD

130. R. L. Parks, Underwriters Laboratories, Inc., Northbrook, IL

131. F. J. Powell, National Bureau of Standards, Gailler'slury, MD

132. A. Rodin, American Home Lighting Institute, Chicago, IL

133. J. M. Roehm, PO Dü 887, Viryillid Bedch, VA

134. H. D. Ross, DOE/BCS, Washington, DC

135. T. Ryan, National Electrical Manufacturers Assoc., Washington, DC

136. E. Schaffer, Forest Products Laboratory, Madison, WI

137. S. Selkowitz, Lawrence Berkeley Laboratory, Berkeley, CA

138. M. Shahin, CERL, Champaign, IL

139. M. Sherman, Jim Walters Research Corporation, St.. Petersburq, FL

140. C. J. Shirtliffe, National Research Council, Ottawa, Canada

141. M. K. Snyder, Butler Mfg., Co. Research Center, Grandview, Mo

142. R. Sunderegger, Lawrence Berkeley Laboratory, Berkeley, CA

143. E. Stamper, New Jersey Institute of Technology, Newark, NJ

144. J. R. Tanck, DOE/BCS, Washington, DC

145. G. J. Teitsma, Dow Chemical Company, Granville, $\mathrm{OH}$

146. Thomas Industries, Louisville, KY

147. C. L. Tien, University of California, Berkeley, CA 
148-157. I. Toor, Tennessee Technological University, Cookeville, TN

158. H. R. Trechsel, National Bureau of Standards, Gaithersburg, MD

159. G. A. Tsongas, Portland State University, Portland, OR

160. R. P. Tye, Fiber Materials, Inc., Biddeford, ME

161. C. R. Vander Linden, Johns-Manville Sales Corporation, Denver, Co

162. J. D. Verschoor, Johns-Manville R\&D Center, Denver, CO

163. R. Viau, Product Safety Branch, Place Du Portage, Ottawa, Canada

164. S. S. Waddle, DOE/ORO, Oak Ridge, TN

165. R. Weil, Stevens Institute of Technology, Hoboken, NJ

166. Office of Assistant Manager for Energy Research and Development, DOE/ORO, Oak Ridge, IN

167-438. For distribution as shown in TID-4500 under category UC-95d. 